Zabytkoznawstwo i Konserwatorstwo XLII, Toruń 2011

Joanna Karbowska-Berent, Alicja B. Strzelczyk, Krzysztof Zykubek, Joanna Jarmiłko

Zakład Konserwacji Papieru i Skóry UMK

\title{
Zniszczenia mikrobiologiczne zbiorów na tle warunków przechowywania w wybranych bibliotekach $\mathbf{i}$ archiwach w Polsce"
}

\section{Wprowadzenie}

$\mathrm{D}$

o najważniejszych zadań bibliotek i archiwów należy gromadzenie książek i różnego rodzaju archiwaliów oraz zachowanie ich w jak najlepszym stanie. Kondycja księgozbiorów i zasobów archiwalnych zależy w ogromnej mierze od warunków, w jakich one się znajduja, a szczególnie od mikroklimatu panującego w pomieszczeniach magazynowych, czyli od wilgotności i temperatury powietrza, intensywności i rodzaju oświetlenia, a także liczby i rodzaju zanieczyszczeń chemicznych powietrza docierających do zbiorów.

Badania prowadzone w latach 2002-2006 sfinansowano z grantu nr PBZ MIN 002/H01/2002 pt. „Kwaśny papier”. Autorzy dziękują dr hab. Elżbiecie Jabłońskiej, prof. UMK, za krytyczne uwagi dotyczące artykułu oraz za użyczenie zdjęć. 
Trudności w zapewnieniu prawidłowych wartości temperatury i wilgotności względnej powietrza w magazynach bibliotecznych/ /archiwalnych, tj. $16-18^{\circ} \mathrm{C}$ i $45-55 \%$, zazwyczaj sa spowodowane błędami technicznymi lub uszkodzeniami budynków, w których te pomieszczenia są ulokowane. Do takich wad należą m.in. nieszczelności pokrycia dachowego, niedrożność systemu rynien i rur spustowych lub niewydolność izolacji przeciwwilgociowych. Zawilgocenie magazynów może być dodatkowo potęgowane przez niewystarczająca wentylację. Procesy te dotyczą całego magazynu lub zachodzą lokalnie, np. w pobliżu często otwieranych okien, przemarzających ścian lub nieszczelnych instalacji wodnych.

Z wilgotnością względną powietrza powyżej 60-65\% ściśle wiąże się zawilgocenie materiałów bibliotecznych i archiwalnych. Badania Nyukshy ${ }^{1}$ wykazały, że jeśli zawartość wody w papierze przekroczy $8 \%$, to pojawia się zagrożenie wzrostem mikroorganizmów. W takich warunkach podłoża papierowe sa zasiedlane głównie przez grzyby pleśniowe, a podłoża pergaminowe i skórzane przez bakterie, w tym promieniowce. W sprzyjajacych warunkach mikroorganizmy rozwijają się i rozmnażają na materiałach bibliotecznych i archiwalnych bardzo szybko, nawet w ciagu kilku lub kilkunastu dni. Stwierdzono, że w początkowym etapie rozwoju moga korzystać ze składników kurzu², potem zazwyczaj rozkładają związki organiczne wchodzące w skład materiałów archiwalnych i bibliotecznych. Jeśli wysoka zawartość wody w papierze utrzymuje się dłużej, kolonie zaczynają rozmnażać się i uwalniać zarodniki do powietrza. Jest to bardzo niebezpieczne, ponieważ potomne mikroorganizmy są już przystosowane do warunków oraz materiałów bibliotecznych/archiwalnych i z łatwością moga osiedlać się na kolejnych, podobnych obiektach.

Celem naszych badań była ocena wpływu warunków przechowywania na zniszczenia mikrobiologiczne zbiorów w wybranych magazynach bibliotecznych i archiwalnych. Jest to jednocześnie kontynuacja prezentacji wyników badania stanu zachowania zbiorów XIX- i XX-wiecznych

1 Yu. P. Nyuksha, Biological principles of book keeping conditions, „Restaurator”, 1979, vol. 3, s. 101-107.

2 A. Korpi, A.-L. Pasanen, P. Pasanen, P. Kalliokoski, Microbial Growth and Metabolism in House Dust, „International Biodeterioration \& Biodegradation”, 1997, vol. 40, s. 19-27. 
w tych placówkach ${ }^{3}$. Konsekwencja badań jest wskazanie związków między warunkami przechowywania zbiorów a ich kondycją oraz dróg rozwiązania problemów dotyczących zagrożeń mikrobiologicznych w magazynach bibliotecznych i archiwalnych.

\section{Materiał i metodyka badań}

Do badań wybrano cztery magazyny biblioteczne i jeden archiwalny (tab. 1). Na wstępie dokonano przeglądu stanu technicznego budynków, w których mieścily się te magazyny, pod kątem ich wad i uszkodzeń (pęknięć murów, niedrożności rynien i rur spustowych, nieszczelności pokryć dachowych). Przeprowadzono również oględziny wybranych magazynów ze szczególnym uwzględnieniem zawilgoceń przegród budowlanych, zacieków, złuszczeń powłok malarskich, a także obecności instalacji grzewczych, klimatyzacyjnych bądź wentylacyjnych. W miejscach zawilgoconych wilgotność masowa przegród budowlanych mierzono wilgotnościomierzem Protimeter Surveymaster SM.

W trzech magazynach (A, B i E) przeprowadzono w ciagu około jednego roku pomiary wilgotności względnej powietrza i temperatury (termohigrometrem Lab-El LB-706G) w 1-8 miejscach w zależności od wielkości magazynu. W magazynie $\mathrm{C}$ wykonano pomiary mikroklimatu dwukrotnie (wiosną i jesienią) w sześciu miejscach.

Do oceny zniszczeń zbiorów zastosowano zmodyfikowaną metodę stanfordzką. Z każdego magazynu wybrano losowo po około 760 obiektów (książek lub poszytów) i oceniono zniszczenia poszczególnych ich części (opraw, wyklejek, kart ochronnych i papierowych bloków) przez organizmy żywe (grzyby, owady lub gryzonie). Stopień każdego rodzaju zniszczenia oceniano w skali od 0 do $3^{4}$. Po zsumowaniu wszystkich

3 A. B. Strzelczyk, K. Zykubek, Ocena zniszczeń mechanicznych, fisykochemicznych i mikerobiologicznych zbiorów z lat 1800-1914, przechowywanych w czterech polskich placówkach bibliotecznych $i$ archiwalnych, „Notes Konserwatorski”, 2007, nr 11, s. 160-180.

4 Oznaczenia: 0 - brak widocznych objawów zniszczenia lub zniszczenia nieznaczne, 1 - niewielkie zniszczenia, 2 - średnie zniszczenia, 3 - silne i bardzo silne zniszczenia. 
ocen obliczono tzw. średnią wartość zniszczenia obiektu, czyli wyrażony w procentach stosunek uzyskanej przez niego liczby punktów do najwyższej możliwej do uzyskania liczby punktów, która wynosiła 60. Na podstawie średnich wartości zniszczenia przyjęto następujące oceny zniszczenia obiektów przez czynniki biologiczne:

- dla średnich wartości zniszczenia $\leq 5 \%$ - obiekty wcale niezniszczone lub zniszczone w minimalnym stopniu;

- dla średnich wartości zniszczenia w przedziale 6-10\% - nieznacznie zniszczone;

- dla średnich wartości zniszczenia w przedziale 11-15\% - średnio zniszczone;

- dla średnich wartości zniszczenia $>15 \%$ - silnie zniszczone.

Materiał do badań mikrobiologicznych z obiektów zaatakowanych przez drobnoustroje pobrano za pomocą trzech metod: metody zeskrobania, metody odcisku na taśmę samoprzylepna (do obserwacji mikroskopowych) oraz metody wymazu. Z materiału pobranego z zastosowaniem metody wymazu wykonywano zawiesiny wodne, które wysiewano na płytki z pożywką za pomocą metody płytek tartych. Do hodowli wykorzystano pożywkę z wyciagiem Malto (Merck) oraz zmodyfikowane pożywki dla bakterii celulolitycznych ${ }^{5}$ i grzybów celulolitycznych ${ }^{6}$. Modyfikacja tych pożywek polegała na zastapieniu sproszkowanej celulozy kwadratami bibuły Whatmana, które wyłożono na powierzchnię pożywek w płytkach Petriego. Inkubację przeprowadzono w temperaturze $28^{\circ} \mathrm{C}$ przez $7 \mathrm{dni}$, po czym zidentyfikowano wyrosłe grzyby, opierając się na kluczach do oznaczania grzybów pleśniowych ${ }^{7}$.

5 B. Berg, B. Hofsten, L. G. Pettersson, Growth and cellulose formation by Cellvibrio fulvus, ,J. Appl. Bacteriology”, 1971, vol. 35, s. 201-214.

$6 \mathrm{~K}$. Aschan, B. Norkrans, A study on the cellulolytic variation for wild types and mutants of Collybia velutipes, „J. Physiol. Plantarum”, 1953, vol. 6, s. 564-583.

7 K. H. Domsch, W. Gams, T.-H. Anderson, Compendium of Soil Fungi, IHW Verlag 1980, reprint 1993; G. S. de Hoog, J. Guarro, Atlas of Clinical Fungi, Centraalbureau voor Schimmelcultures/Universitat Rovira i Virgili 1995. 


\section{Wyniki badań}

W trakcie oględzin stanu technicznego budynków największe problemy zaobserwowano w Bibliotece Głównej UMK i II Oddziale Archiwum Państwowego w Toruniu. W Bibliotece Głównej UMK stwierdzono występowanie zawilgoceń dwojakiego rodzaju. W magazynach znajdujących się w przyziemiu, $\mathrm{t}$. $\mathrm{w}$ magazynie $\mathrm{C}$, mieszczącym się pod gmachem WNEiZ, oraz w Magazynie Czasopism, mieszczącym się pod gmachem BG, po obfitszych opadach w niektórych miejscach były widoczne kałuże stojącej wody. W tzw. łączniku, czyli podziemnym korytarzu prowadzącym do magazynu $C$, wilgotność masowa ściany w obrębie zacieku wynosiła 6,5\%. Źródło zawilgocenia stanowiła tu woda pochodząca z opadów atmosferycznych i przesączająca się do wnętrza pomieszczeń ze studzienek przez nieszczelne drzwi ewakuacyjne lub przez pęknięcia w stropie łącznika.

Drugim miejscem, gdzie występowało zawilgocenie w Bibliotece Głównej UMK, był Magazyn Dubletów położony pod tzw. patio. Patio w gmachu biblioteki to rodzaj niezadaszonego tarasu, z którego woda opadowa częściowo była odprowadzana do dwóch studzienek, a częściowo przesączała się do mieszczącego się poniżej Magazynu Dubletów. Prawie cały sufit tej części magazynu, która znajduje się pod patio, był pokryty zaciekami -towarzyszyły im pęknięcia i odspojenia powłok malarskich (il. 1).

Z kolei źródło zawilgocenia w II Oddziale Archiwum Państwowego w Toruniu stanowiły nieszczelności pokrycia dachowego. Na sufitach, a także na niektórych ścianach magazynów na I piętrze stwierdzono liczne zacieki, zniszczenie powłok malarskich, wysolenia oraz rozwój grzybów pleśniowych (il. 2). Mur w miejscach zacieków był silnie zawilgocony jego wilgotność masowa wynosiła 8-12\%.

We wszystkich wybranych magazynach było ogrzewanie, w dwóch magazynach (B i C) zainstalowano urządzenia klimatyzacyjne, a w jednym (D) wentylację nawiewowo-wywiewowa. Niektóre magazyny znajdowały się w miejscach narażonych na zawilgocenie, np. na ostatniej kondygnacji budynku (A) lub w przyziemiu (C) (tab. 2).

W magazynach, w których pomiary parametrów klimatycznych przeprowadzano prawie przez rok (A, B i E), średnie wartości RH powietrza 
mieściły się w zakresie 46,0-47,4\%, a średnie temperatury w zakresie 19,5-21,0 ${ }^{\circ} \mathrm{C}$. Zmienność tych parametrów w okresie badawczym była bardzo duża (tab. 3, rys. 1). Najniższe temperatury przypadały na styczeń i wczesna jesień, najniższe wartości RH notowano w styczniu lub wczesną wiosna. Najwyższe temperatury i wartości RH przypadały w miesiącach letnich.

Zależność parametrów klimatycznych od pór roku była także widoczna w magazynie C. Jesienią średnia temperatura z sześciu miejsc pomiaru w tym magazynie wynosiła $21,7^{\circ} \mathrm{C}$, a $\mathrm{RH} 33,5 \%$, wiosna odpowiednio $18,5^{\circ} \mathrm{C}$ i $44,8 \%$.

Stopień zniszczenia zbiorów przez czynniki biologiczne (grzyby, owady i gryzonie) był zbliżony we wszystkich zbadanych magazynach. Średnio około 72,3\% zbiorów (60-84,4\% w zależności od magazynu) stanowiły obiekty, w których nie stwierdzono tego rodzaju zniszczeń. Niepokój budzi jednak fakt, że pozostała część zbiorów - średnio około 27,7\% (25,6-40\% w zależności od magazynu) była w mniejszym lub większym stopniu zniszczona przez organizmy żywe. Książki bądź dokumenty silnie zniszczone stanowily kilka procent $(0,2-6,3 \%$ ) (rys. 2).

W magazynie B stwierdzono obecność żywych postaci doskonałych owadów mrzyka gabinetowego Anthrenus verbasci L., szubaka dwukropka Attagenus pellio L. (il. 3) i rybika cukrowego Lepisma saccharina L. Napotykano zniszczenia spowodowane żerowaniem rybika cukrowego Lepisma saccharina L. (il. 4) lub gryzoni (il. 5, rys. 3).

Zniszczenia mikrobiologiczne w zbadanych placówkach obejmowały papier w bloku książki, karty ochronne, wyklejki oraz oprawy. Najczęściej obserwowanym zniszczeniem były żółtobrązowe lub czerwonobrązowe, niewielkie zaplamienia typu foxing (il. 6, rys. 3). Zaobserwowano, że przeważnie pokrywały one papiery gorszej jakości, z których były wykonane wyklejki, karty ochronne, papierowe przekładki, a także tektury usztywniające i papiery wyklejające wnętrza teczek. Foxing zauważono nawet na tkaninach - na płóciennych teczkach i tasiemkach, którymi teczki były przewiązane.

Rzadziej napotykano różnego rodzaju zmiany barwne spowodowane przez rozwój grzybów pleśniowych i puszysta destrukcję (il. 7-9, rys. 3, tab. 4). Wśród zmian barwnych pochodzenia mikrobiologicznego 
zaobserwowano naloty ziarniste, puszyste lub pudrowate - w kolorach białym lub rdzawoczerwonym - oraz różnej wielkości zaplamienia w kolorach: białym, kremowym, różowym, czerwonym, fioletowym bądź szarym, przeważnie przenikające przez kilka kartek papieru. Zmianom barwnym zazwyczaj towarzyszyło ścienienie lub rozpulchnienie papieru, jego osłabienie, a nawet ubytki, czyli objawy świadczące o jego rozkładzie. Występowanie tych oznak zniszczeń często odnotowywano w miejscach zawierających dużą ilość klejów (okładziny, wyklejki, naklejki z sygnaturami, ekslibrisy), które są na ogół łatwiej przyswajalną pożywką niż celuloza.

Obserwacje mikroskopowe materiału pobranego za pomoca metody odcisku na taśmę klejąca z miejsc zniszczonych przez mikroorganizmy wykazały dużą różnorodność drobnoustrojów. Widoczne były liczne zarodniki różnych grzybów, fragmenty strzępek, a nawet całe konidiofory. Najczęściej identyfikowano grzyby z rodzajów Aspergillus, Penicillium, Cladosporium, rzadziej Chaetomium, Rhizopus, Alternaria, Trichothecium, Sporothrix, Ulocladium, Acremonium, Sepedonium, Botrytis, Stachybotrys i Botryotrichum. Grzybom towarzyszyły bakterie, głównie Gram(+) ziarniaki i promieniowce (tab. 4).

W 41 posiewach z 48 ogółem wykonanych stwierdzono wzrost drobnoustrojów, co stanowi $85 \%$ posiewów. Wyrosłe grzyby należały przeważnie do rodzajów powszechnie występujących w kurzu, takich jak Penicillium i Cladosporium, w pojedynczych przypadkach do rodzajów Trichothecium, Acremonium, Aspergillus, Mucor, Verticillium, Ulocladium. Niektóre grzyby wytwarzały w hodowlach tylko grzybnię. Grzybom towarzyszyły bakterie, głównie Gram(+) ziarniaki, laseczki przetrwalnikujące, promieniowce, rzadziej Gram(-) pałeczki (tab. 4). W jedenastu posiewach na 41, w których wyrosły drobnoustroje (co stanowi $27 \%$ ), stwierdzono wzrost drobnoustrojów celulolitycznych.

\section{Dyskusja}

Wyniki przeprowadzonych badań wskazują na wpływ obecnych i dawnych warunków przechowywania na zagrożenie zbiorów w bibliotekach i archiwach mikroorganizmami. 
Zniszczenia powodowane przez grzyby i bakterie są zawsze skutkiem obecności w podłożu wody dostępnej dla mikroorganizmów. Przyczyn pojawiania się wody $\mathrm{w}$ magazynach bibliotecznych i archiwalnych zazwyczaj należy upatrywać w wadach i uszkodzeniach budynku, w którym mieszczą się magazyny. W przedstawionych badaniach potwierdzono bezpośrednią zależność między wadami i uszkodzeniami budynku a zawilgoceniem przegród budowlanych magazynów. W rozpatrywanych magazynach była to woda pochodząca z opadów atmosferycznych i przesączająca się do wnętrza różnymi drogami: przez nieszczelne drzwi ewakuacyjne, przez pęknięcia w stropie, z przepełnionych studzienek kanalizacyjnych, wskutek nieszczelności pokrycia dachowego lub pokrycia tarasu. Pozostałościami tych okresowych zalań były zacieki na ścianach i sufitach. Wilgotność masowa w obrębie zacieków dochodziła do $12 \%$, czyli znacznie przekraczała wartość graniczną 4\%, powyżej której mur uważa się za zawilgocony. W następstwie zawilgocenia przegród budowlanych w miejscach niektórych zacieków utworzyły się wyraźne, czarne, białe lub brązowe naloty grzybów pleśniowych ${ }^{8}$.

Zawilgocenie przegród budowlanych powoduje wzrost wilgotności względnej powietrza w pomieszczeniach. W magazynach, w których przeprowadzano pomiary parametrów klimatycznych przez prawie rok, nie było widocznych śladów zawilgocenia przegród budowlanych i średnia wilgotność względna powietrza mieściła się w zalecanym dla magazynów zakresie wartości (45-55\%). Jednak zaobserwowano bardzo duże, dochodzące do 30\%, wahania tego parametru w ciagu roku, co oznacza, że do przekroczenia zalecanych wartości wilgotności powietrza dochodziło okresowo, np. bardziej wilgotno było latem, szczególnie po opadach deszczu, a za sucho w sezonie grzewczym. Nieprawidłowe wartości mogły też występować lokalnie, np. w pobliżu okien, nieszczelnych drzwi lub włączonych kaloryferów.

Wyniki pomiarów temperatury wykazały, że we wszystkich zbadanych magazynach było za ciepło, średnie temperatury były bowiem o $1,5-3^{\circ} \mathrm{C}$ wyższe, niż przewiduja zalecenia dla magazynów bibliotecznych i archiwalnych (temperatura w magazynach powinna mieścić się

8 A. B. Strzelczyk, K. Zykubek, op. cit. 
w zakresie $\left.16-18^{\circ} \mathrm{C}\right)$. Wartości temperatury również były bardzo zmienne i w dużym stopniu dyktowane warunkami panującymi na zewnattrz. W magazynie B, klimatyzowanym latem i wentylowanym zima, wahania parametrów klimatycznych były podobne jak w nieklimatyzowanych magazynach E i A. Trudności z utrzymaniem stałej temperatury w tym pomieszczeniu potęgowała obecność 20 okien nieosłoniętych roletami ani żaluzjami ${ }^{9}$. Najstabilniejsze warunki panowały w usytuowanym na parterze, nieklimatyzowanym magazynie E.

Przeprowadzone równolegle badania liczebności mikroorganizmów w powietrzu w magazynach na stanowiskach pracy wykazały dość niskie całkowite stężenia bioaerozoli. Mieściły się one w zakresie 142-798 jtk/ $/ \mathrm{m}^{3}$, czyli znacznie poniżej $5000 \mathrm{jtk} / \mathrm{m}^{3}$, a więc limitu dla stężeń bioaerozolu przyjętego dla pomieszczeń użyteczności publicznej ${ }^{10}$.

Jednak w magazynach bibliotecznych/archiwalnych szczególnie istotne jest stężenie aerozolu grzybowego, ponieważ grzyby pleśniowe sa poważnym zagrożeniem dla zbiorów, a niektóre mogą mieć szkodliwy wpływ na zdrowie pracowników ${ }^{11}$. Stężenia aerozolu grzybowego w czterech z pięciu zbadanych magazynów były niskie i wynosiły $51-86 \mathrm{jtk} / \mathrm{m}^{3}$, czyli również mieściły się poniżej zalecanych limitów ${ }^{12}$. Większość autorów przyjmuje bowiem, że stężenie aerozolu grzybowego w magazynach bibliotecznych nie powinno przekraczać 100-120 jtk/m³ lub $150 \mathrm{jtk} / \mathrm{m}^{3}$

9 E. Jabłońska, Biblioteka Kórnicka skarbnica zbiorów Dz̧iatynskich i Zamoyskich. Ocena stanu zachowania starodruków i rekopisów ₹ XIX/XX wieku. Problemy konserwacji i restauracji, Toruń 2005.

10 jtk - jednostki tworzace kolonie, np. zarodniki lub fragmenty strzępek grzybów; J. Karbowska-Berent, R. Górny, A. Strzelczyk, A. Wlazło, Microbial quality in selected Polish libraries and archives, „Building and Environment”, 2011, vol. 48, s. 1872-1879.

11 G. S. de Hoog, Risk assessment of fungi reported from humans and animals, „Mycoses”, 1996, vol. 39, s. 407-417; E. Baran, Mikologia lekarska, Wrocław 1998; A. Lipiec, Grayby plésniowe - ważny alergen środowiskowy, „Terapia”, 1997, nr 3, s. 27-29; M. Wiszniewska, J. Walusiak, I. Pannenko, M. Draniak, M. Kowalczyk, C. Pałczyński, Plésnie - alergen obecny w środowisku pracy muzealników, IV Konferencja Naukowa „Rozkład i Korozja Mikrobiologiczna Materiałów Technicznych”, Łódź 2006, s. 262-265; J. Karbowska-Berent, D. Jarosińska, M. Muszyńska-Graca, Ocena stopnia narażenia pracownikón bibliotek $i$ archiwón na alergie i graybice w środowisku pracy, „Notes Konserwatorski”, 2007, nr 11, s. 255-266.

12 J. Karbowska-Berent, R. Górny, A. Strzelczyk, A. Wlazło, op. cit. 
(pod warunkiem, że stężenie żadnego gatunku nie przekracza $50 \mathrm{jtk} / \mathrm{m}^{3}$ ), względnie $200 \mathrm{jtk} / \mathrm{m}^{313}$.

Wyższe stężenia aerozolu grzybowego sygnalizują obecność wewnętrznego źródła grzybów, występowanie zawilgocenia w magazynie lub co najmniej silnego zakurzenia zbiorów. Każdy z tych powodów powinien skłaniać pracowników bibliotek czy archiwów do interwencji mającej na celu usunięcie nadmiaru mikroorganizmów. Tak było w magazynie $\mathrm{C}$, gdzie zanotowano wysoki stopień zanieczyszczenia powietrza grzybami $\left(490 \mathrm{jtk} / \mathrm{m}^{3}\right)$. W magazynie tym zachodził wyraźny związek między okresowymi zalaniami przez wody opadowe a wysokim stężeniem aerozolu grzybowego. Dzięki temu, że przeprowadzono remont i usunięto nieszczelności, przez które przedostawała się woda opadowa, oraz wykonano mechaniczne oczyszczanie zbiorów odkurzaczem wodnym, stężenie aerozolu grzybowego spadło do poziomu $160 \mathrm{jtk} / \mathrm{m}^{3}$, a więc uzyskano jego ponadtrzykrotną redukcję ${ }^{14}$.

W każdym ze zbadanych magazynów około 1/4 zbiorów została w mniejszym lub większym stopniu uszkodzona przez organizmy żywe. Niektóre zagrożenia były nadal aktualne, np. atak szubaka dwukropka i mrzyka gabinetowego w magazynie B, i wymagały natychmiastowej interwencji. Jednak wiele innych zniszczeń, szczególnie spowodowanych przez mikroorganizmy, powstało w przeszłości i odpowiedzialne za nie drobnoustroje od dawna mogły być nieaktywne. Z tego względu trudno znaleźć korelację między wynikami badań mikroskopowych nalotów pobranych z miejsc zaatakowanych a wynikami posiewów i hodowli mikroorganizmów z tych samych miejsc.

Zbiory sa bowiem przechowywane $\mathrm{w}$ zbadanych magazynach od 10-30 lat, czyli stosunkowo krótko. $\mathrm{Na}$ ich kondycję w większym stopniu

13 M. Piotrowska, K. Zielińska-Jankiewicz, A. Kozajda, B. Gutarowska, Zanieczyszczenie powietrza grzybami strzepkowymi w archiwach i bibliotekach, IV Konferencja Naukowa „Rozkład i Korozja Mikrobiologiczna Materiałów Technicznych”, Łódź 2006, s. 176-179; J. Karbowska-Berent, R. Górny, A. Strzelczyk, A. Wlazło, op. cit.; F. Flieder, Ch. Capderou, Sawvegarde des collections du Patrimoine. La lutte contre les détériorations biologiques, CNRS Éditions, 1999; Z. Cieplik, Zagraybienie ksiegozbioru Biblioteki Polonistycznej Wydziału Filologicznego Uniwersytetu Ślaskiego, „Studia Bibliologiczne”, 1997, nr 10, s. 107-119.

14 J. Karbowska-Berent, R. Górny, A. Strzelczyk, A. Wlazło, op. cit. 
wpłynęły burzliwe losy w ciagu dziesiątek lat poprzedzających umieszczenie ich w tych magazynach (przechowywanie w piwnicach, na poddaszach, przeprowadzki, wojny). Zniszczenia mikrobiologiczne, które powstały w tamtych, często nieprawidłowych dla przechowywania zbiorów warunkach, obecnie są nadal widoczne, ale niekoniecznie aktywne. Żywotność mikroorganizmów można badać tradycyjnymi metodami hodowlanymi lub nowszą metodą bioluminometryczną - dzięki niej wynik uzyskuje się po kilku minutach bez konieczności hodowli. Istotą metody bioluminometrycznej jest przekształcenie się energii chemicznej zawartej w wysokoenergetycznych cząsteczkach ATP ${ }^{15}$ w światło, którego intensywność jest skorelowana z ilością tego związku na badanej powierzchni, a tym samym w przybliżeniu z liczbą obecnych na niej żywych mikroorganizmów ${ }^{16}$.

Informacja o stopniu żywotności mikroorganizmów jest ważna przy podejmowaniu decyzji o dezynfekcji zbiorów. Każda decyzja o dezynfekcji za pomoca metod chemicznych lub fizycznych zarówno zbiorów, jak i pojedynczych obiektów powinna być poprzedzona badaniami mikrobiologicznymi, które pozwolą ustalić, czy mikroorganizmy są aktywne i czy dezynfekcja jest rzeczywiście niezbędna. Niektórzy autorzy uważaja nawet, że zagrzybione obiekty można pozostawić bez dezynfekcji, ponieważ grzyby nie rozwiną się na zbiorach, jeśli będą one przechowywane w prawidłowych warunkach i po pewnym czasie obumra, natomiast w razie zawilgocenia czy zalania zbiorów i tak może dojść do rozwoju zarodników grzybów z powietrza ${ }^{17}$.

15 ATP (adenozyno-5-trifosforan) - związek zawierający wysokoenergetyczne wiązania, który magazynuje i dostarcza energię konieczną do większości procesów życiowych w komórkach roślin, zwierząt i mikroorganizmów. Występuje tylko w żywych komórkach, a po ich śmierci szybko ulega rozpadowi.

16 J. Karbowska-Berent, I. Kotala, Bioluminescencja - szybka metoda wykerywania ìywych drobnoustrojów na powierz̨chniach zabytków - wyniki wstepnych badań, „Biuletyn Informacyjny Konserwatorów Dzieł Sztuki”, 2006, nr 17, s. 64-65.

17 A. Haberditzl, Was tun mit schimmelbefallenen Archivalien und Büchern? Betrachtungen zum Allheilmittel Desinfektion, [w:] Bestandserhaltung, Herausforderung und Chancen, hrsg. von H. Weber, Stuttgart 1997, s. 259-281; R. Fuchs, Zwalczanie škodników na qaatakowanym materiale bibliotecznym $i$ archiwalnym - porównanie starych $i$ nowych metod. Nowoczesne metody badawcze do porównania zmian w strukturze molekularnej, „Ochrona Zabytków”, 1998, nr 51, s. 63-79. 
Podsumowując, uzyskane wyniki pokazują, że wady i uszkodzenia budynków prowadzą w pierwszej kolejności do zawilgocenia i towarzyszącego mu zagrzybienia przegród budowlanych, następnie do lokalnego wzrostu wilgotności względnej powietrza, a dopiero wskutek tego do zawilgocenia zbiorów i rozwoju w nich mikroorganizmów. Tempo tych procesów może być bardzo różne - w przypadku powodzi do katastrofalnego rozwoju mikroorganizmów dochodzi w ciagu kilku lub kilkunastu dni, natomiast w przypadku okresowych zalań przez nieszczelności w dachu, wahań parametrów klimatycznych lub braku wentylacji zniszczenia wywołane przez mikroorganizmy mogą pojawić się po kilku tygodniach lub miesiącach.

Każda ocena warunków przechowywania zbiorów pod kątem ich narażenia na czynniki biologiczne powinna zaczynać się od oględzin stanu technicznego budynku i pomieszczeń magazynowych. W razie stwierdzenia nieprawidłowości należy przeprowadzić konieczne remonty i naprawy, co pozwoli wyeliminować przyczynę problemów. Przy planowaniu lokalizacji magazynów trzeba wziąć pod uwagę, że piwnice i ostatnie kondygnacje budynków są najbardziej narażone na pojawienie się wspomnianych wad i uszkodzeń i na zawilgocenie.

Ponadto, w każdym magazynie muszą być prowadzone pomiary wilgotności względnej powietrza i temperatury, co umożliwi szybkie wykrycie ewentualnych nieprawidłowości. Urządzenia pomiarowe lub ich czujniki powinny być umieszczone w miejscach, w których jest duże prawdopodobieństwo wystąpienia nieprawidłowości, np. przy ścianach zewnętrznych lub w narożnikach pomieszczeń, gdzie panuje słaba wentylacja.

W razie stwierdzenia nalotów lub plam wskazujących na rozwój mikroorganizmów, zarówno na zbiorach, jak i na przegrodach budowlanych, konieczne są badania mikrobiologiczne w celu określenia poziomu żywotności mikroorganizmów. Jeśli potwierdzą one, że atak mikroorganizmów jest aktywny, należy przeprowadzić dezynfekcję dostępnymi metodami. W magazynach, w których pojawiały się problemy związane z rozwojem mikroorganizmów, trzeba okresowo badać stężenia bioaerozoli.

Niezależnie od ewentualnych infekcji mikrobiologicznych, co pięć lat zaleca się mechaniczne oczyszczanie zbioru ${ }^{18}$ - jego celem jest m.in.

18 PN-ISO 11 799, czerwiec 2006: Informacja i dokumentacja. Wymagania dotyczące warunków przechowywania materiałów archiwalnych i bibliotecznych. 
zmniejszenie liczebności mikroorganizmów, które moga zagrażać zbiorom oraz oddziaływać szkodliwie na zdrowie ludzi. Należy jednak pamiętać, że mikroorganizmy są wszechobecne i ich całkowita eliminacja z magazynów bibliotecznych/archiwalnych nie jest możliwa ani konieczna. Kluczowym czynnikiem, decydującym o pojawieniu się problemów mikrobiologicznych w magazynie, jest obecność nadmiernej ilości dostępnej dla mikroorganizmów wody.

Tab. 1. Placówki objęte badaniami

\begin{tabular}{|c|c|c|}
\hline Biblioteki i archiwa & Magazyny wybrane do badań & $\begin{array}{c}\text { Symbol } \\
\text { magazynu }\end{array}$ \\
\hline \multirow{2}{*}{ Biblioteka Kórnicka PAN } & magazyn zamkowy (nr 5) & A \\
\cline { 2 - 3 } & magazyn współczesny (nr 102) & B \\
\hline Biblioteka Główna UMK w Toruniu & $\begin{array}{c}\text { magazyn pod Wydziałem Nauk Ekonomicznych } \\
\text { i Zarządzania (WNEiZ) }\end{array}$ \\
\hline $\begin{array}{c}\text { Wojewódzka Biblioteka Publiczna } \\
- \text { Książnica Kopernikańska }\end{array}$ & magazyn gazet (nr IV) & D \\
\hline Archiwum Państwowe II Oddział w Toruniu & magazyn akt metrycznych (nr XVIII) & E \\
\hline
\end{tabular}

Tab. 2. Krótka charakterystyka wybranych magazynów

\begin{tabular}{|c|l|}
\hline Magazyn & \multicolumn{1}{|c|}{ Położenie, zbiory i wyposażenie wybranych magazynów } \\
\hline A & $\begin{array}{l}\text { Magazyn znajduje się na ostatniej kondygnacji południowo-zachodniej wieży. Od 1997 r. gromadzi } \\
5,5 \text { tys. woluminów archiwaliów (archiwum rodowe Działyńskich i Zamoyskich), które przedtem prze- } \\
\text { chowywano w przyziemiu zamku. Woluminy są umiejscowione na drewnianych regałach z przełomu XIX } \\
\text { i XX w. W magazynie jest ogrzewanie, brak klimatyzacji i dróg wentylacyjnych }\end{array}$ \\
\hline B & $\begin{array}{l}\text { Magazyn znajduje się na I piętrze nowego magazynu bibliotecznego (zbud. 1987-1993). Gromadzi ręko- } \\
\text { pisy, gł. z XIX i XX w., i zbiory współczesne (książki, gazety). Zbiory są umiejscowione na metalowych, } \\
\text { otwartych regałach. Magazyn jest ogrzewany i klimatyzowany zimą oraz wentylowany latem. W maga- } \\
\text { zynie jest 20 nieosłoniętych okien }\end{array}$ \\
\hline C & $\begin{array}{l}\text { Magazyn wybudowano w 1995 r. w przyziemiu pod WNEiZ. Z biblioteką jest połączony podziemnym } \\
\text { łącznikiem. W magazynie jest przechowywany księgozbiór z XIX i XX w. Książki stoją na metalowych, } \\
\text { malowanych regałach. W magazynie i łączniku po obfitszych opadach pojawia się woda, czego efektem } \\
\text { są m.in. zacieki do wysokości ok. 15 cm od podłogi widoczne na ścianie wschodniej. W magazynie jest } \\
\text { zainstalowana klimatyzacja i ogrzewanie }\end{array}$ \\
\hline D & $\begin{array}{l}\text { Magazyn mieści się na II piętrze budynku biblioteki, która została oddana do użytku w 1973 r. Są w nim } \\
\text { przechowywane czasopisma i gazety codzienne. W magazynie jest ogrzewanie i wentylacja nawiewo- } \\
\text { wo-wywiewowa. Nie zaobserwowano zacieków, odspojeń powłok malarskich ani pęknięć czy ubytków } \\
\text { tynku }\end{array}$ \\
\hline E & $\begin{array}{l}\text { Magazyn znajduje się na parterze budynku. Archiwalia są przechowywane na metalowych, otwartych } \\
\text { regałach. W magazynie jest ogrzewanie, brak klimatyzacji i wentylacji }\end{array}$ \\
\hline
\end{tabular}


Tab. 3. Parametry klimatyczne powietrza w magazynach w ciagu roku

\begin{tabular}{|c|c|c|c|c|c|c|c|}
\hline \multirow{2}{*}{ Mag. } & \multirow{2}{*}{$\begin{array}{c}\text { Liczba } \\
\text { miejsc } \\
\text { pomiaru }\end{array}$} & \multicolumn{3}{|c|}{ Temperatura ['C] } & \multicolumn{3}{c|}{ Wilgotność względna [\%] } \\
\cline { 3 - 8 } & średnia & zakres & amplituda & średnia & zakres & amplituda \\
\hline A & $8^{*}$ & 19,5 & $9,9-27,4$ & 17,5 & 47,3 & $35,1-60,0$ & 24,9 \\
\hline B & $7^{*}$ & 21,0 & $15,4-26,4$ & 11,0 & 46,0 & $31,0-60,0$ & 29,0 \\
\hline E & 1 & 20,2 & $17,4-23,2$ & 5,8 & 47,4 & $39,0-58,0$ & 19,0 \\
\hline
\end{tabular}

* Dwa razy dziennie - o 8.00 i 14.30 .

Tab. 4. Wyniki badań mikrobiologicznych wybranych obiektów ze zbadanych magazynów

\begin{tabular}{|c|c|c|c|c|c|}
\hline Mag. & $\begin{array}{l}\text { Sygnatura } \\
\text { obiektu }\end{array}$ & $\begin{array}{l}\text { Miejsce } \\
\text { pobrania } \\
\text { próbki }\end{array}$ & $\begin{array}{c}\text { Objawy } \\
\text { zniszczenia }\end{array}$ & $\begin{array}{l}\text { Mikroorganizmy w ba- } \\
\text { daniu mikroskopowym }\end{array}$ & $\begin{array}{l}\text { Mikroorganizmy wyhodo- } \\
\text { wane na pożywkach }\end{array}$ \\
\hline \multirow{2}{*}{ A } & BK 6419 & oprawa & $\begin{array}{l}\text { czarne zapla- } \\
\text { mienia }\end{array}$ & Cladosporium sp. & $\begin{array}{c}\text { drożdże, Gram-dodatnie } \\
\text { pałeczki przetrwalnikujące }\end{array}$ \\
\hline & BK 4691 & oprawa & $\begin{array}{l}\text { jasnoszare } \\
\text { zaplamienia }\end{array}$ & Penicillium sp. & Penicillium sp. \\
\hline \multirow{3}{*}{ B } & \multirow{2}{*}{ BK 11247} & $\begin{array}{l}\text { papier } \\
\text { w bloku }\end{array}$ & $\begin{array}{l}\text { czarny nalot, } \\
\text { tłuste zapla- } \\
\text { mienia }\end{array}$ & Cladosporium sp. & $\begin{array}{l}\text { Aspergillus sp., bakterie } \\
\text { (ziarniaki Gram-dodatnie, } \\
\text { pałeczki przetrwalnikujące) }\end{array}$ \\
\hline & & oprawa & $\begin{array}{l}\text { jasnoszare } \\
\text { zaplamienia }\end{array}$ & $\begin{array}{l}\text { bakterie (laseczki), } \\
\text { promieniowce }\end{array}$ & Penicillium sp. \\
\hline & BK 11111 & $\begin{array}{l}\text { papierowa } \\
\text { pieczęć na } \\
\text { oprawie }\end{array}$ & $\begin{array}{l}\text { brązowe } \\
\text { naloty }\end{array}$ & $\begin{array}{c}\text { liczne, małe, owalne } \\
\text { zarodniki }\end{array}$ & Penicillium sp. \\
\hline C & 24213 & oprawa & $\begin{array}{l}\text { białe zapla- } \\
\text { mienia }\end{array}$ & $\begin{array}{l}\text { Aspergillus sp. (koni- } \\
\text { diofory i zarodniki) }\end{array}$ & nie badano \\
\hline$E$ & $\begin{array}{c}802 \\
\mathrm{l} / 161.231-233 \\
304.345\end{array}$ & $\begin{array}{l}\text { grzbiet } \\
\text { poszytu }\end{array}$ & $\begin{array}{l}\text { szare zapla- } \\
\text { mienia }\end{array}$ & $\begin{array}{l}\text { Aspergillus sp., } \\
\text { bakterie }\end{array}$ & $\begin{array}{l}\text { Alternaria sp., grzyb nieza- } \\
\text { rodnikujacy, Gram-ujemne } \\
\text { pałeczki w łańcuszkach }\end{array}$ \\
\hline
\end{tabular}




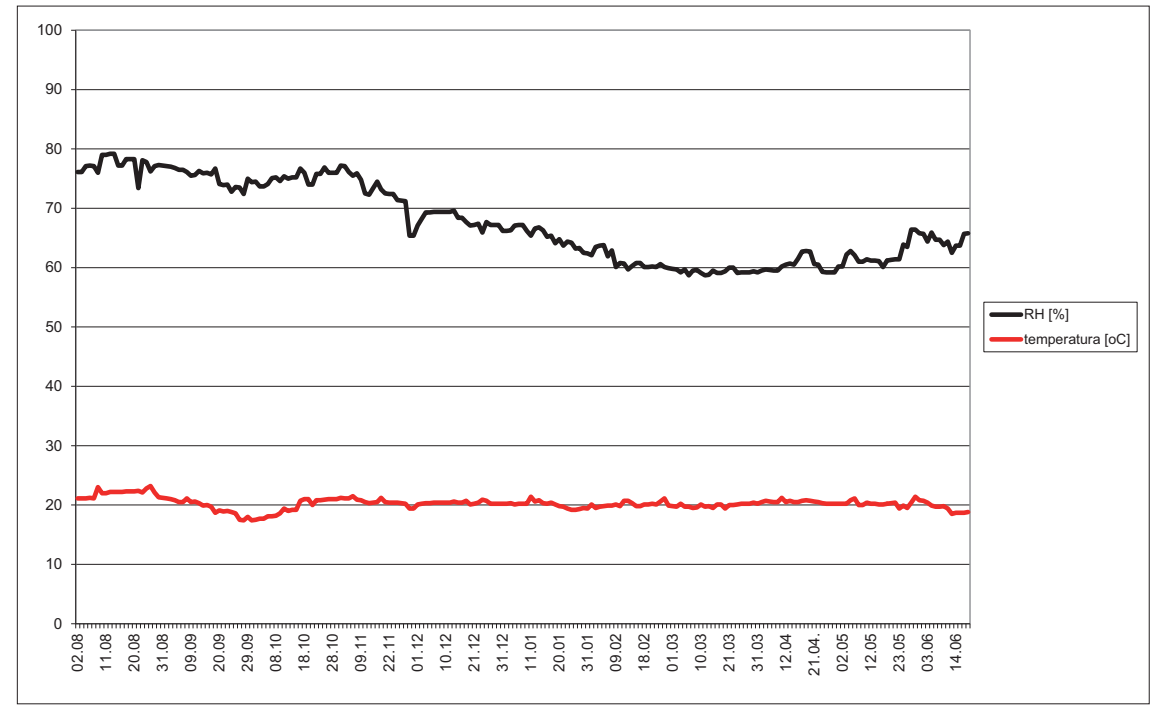

Rys. 1. Mikroklimat w magazynie E w okresie 2.08.2004-17.06.2005

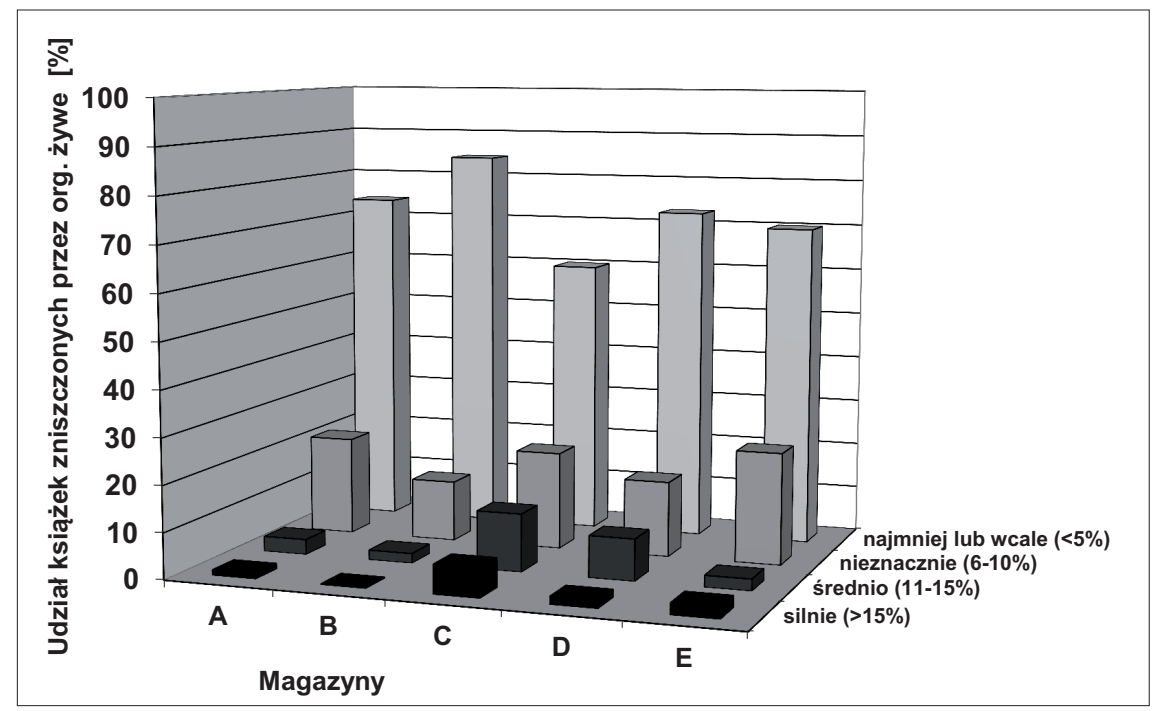

Rys. 2. Stopień zniszczenia przez czynniki biologiczne książek i archiwaliów (z lat 1800_ -1914) w zbadanych magazynach. (Uwaga: D - książki pochodziły z różnych magazynów WBP KK w Toruniu, E - archiwalia pochodziły z różnych magazynów AP II Oddz. w Toruniu) 


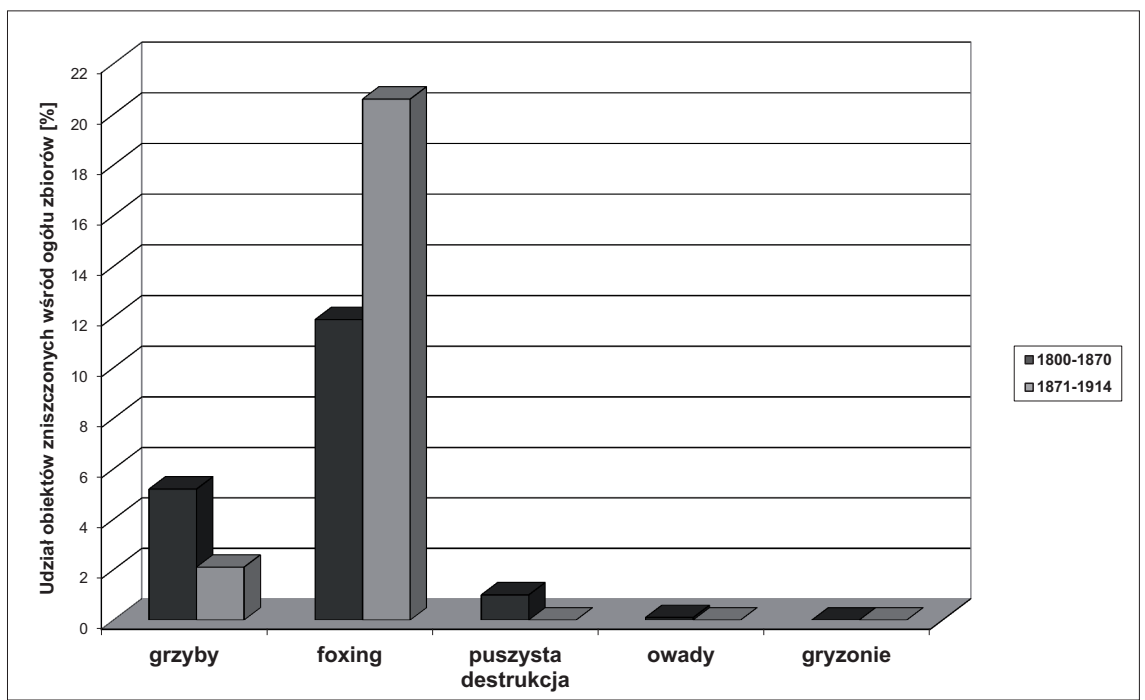

Rys. 3. Częstość występowania zniszczeń powodowanych przez organizmy żywe na przykładzie archiwaliów z II Oddziału Archiwum Państwowego w Toruniu

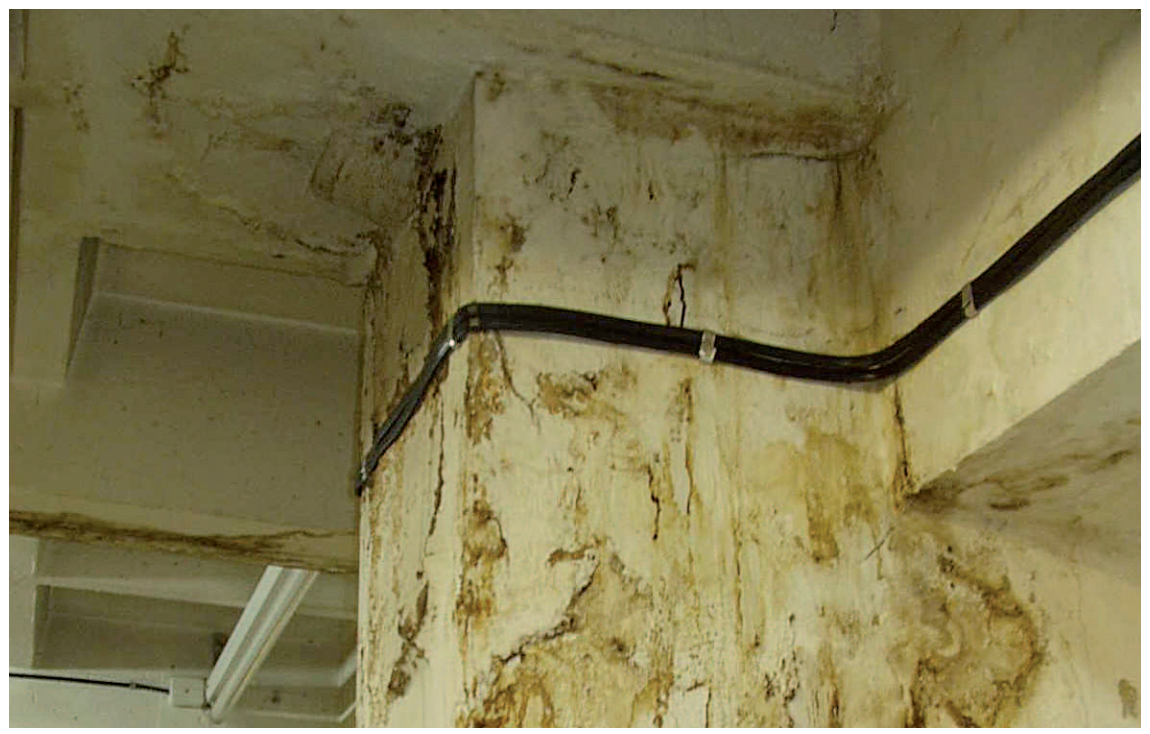

Il. 1. Zacieki w Magazynie Dubletów położonym pod patio (fot. K. Zykubek) 


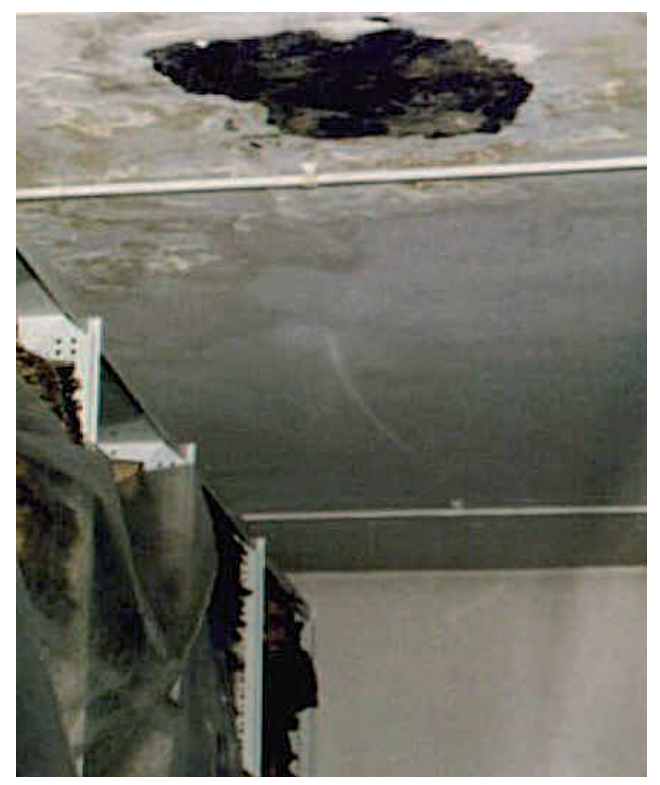

Il. 2. Zacieki, białe wysolenia i czarne plamy kolonii grzybowych na suficie na I piętrze AP (mag. XXV) (fot. K. Zykubek)

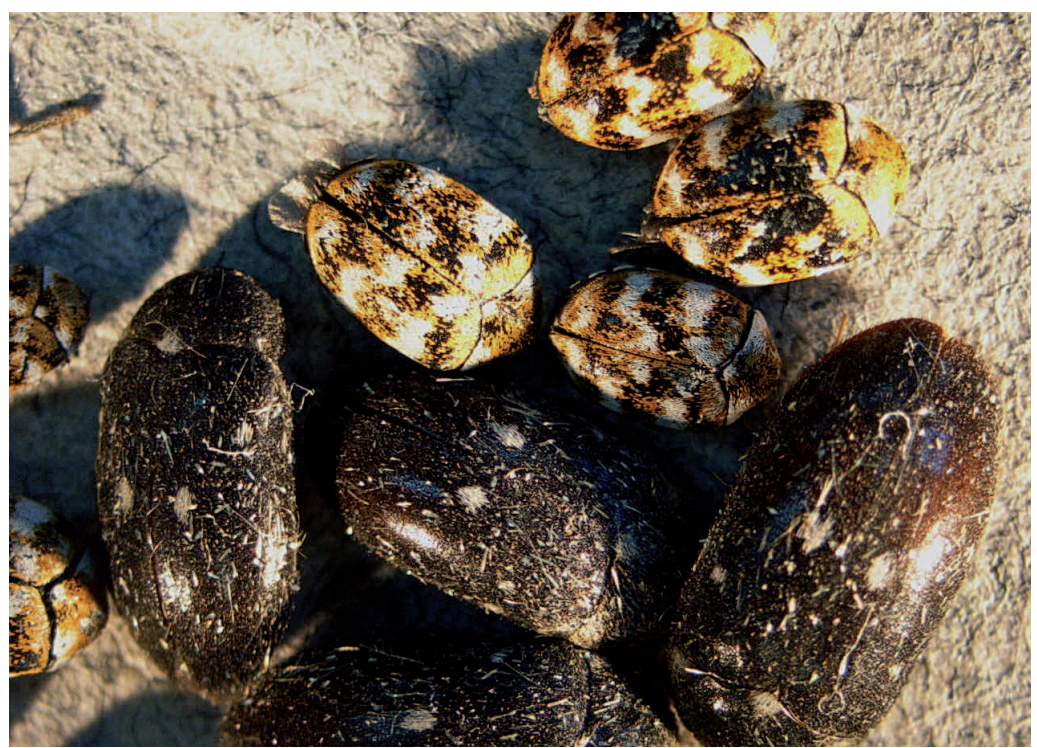

Il. 3. Postacie doskonałe chrzaszczy w magazynie B: mniejsze, z barwnym deseniem na pokrywach, to mrzyki gabinetowe Anthrenus verbasci L., większe, czarne z dwiema białymi kropkami na pokrywach, to szubaki dwukropki Attagenus pellio L. (fot. K. Zykubek) 


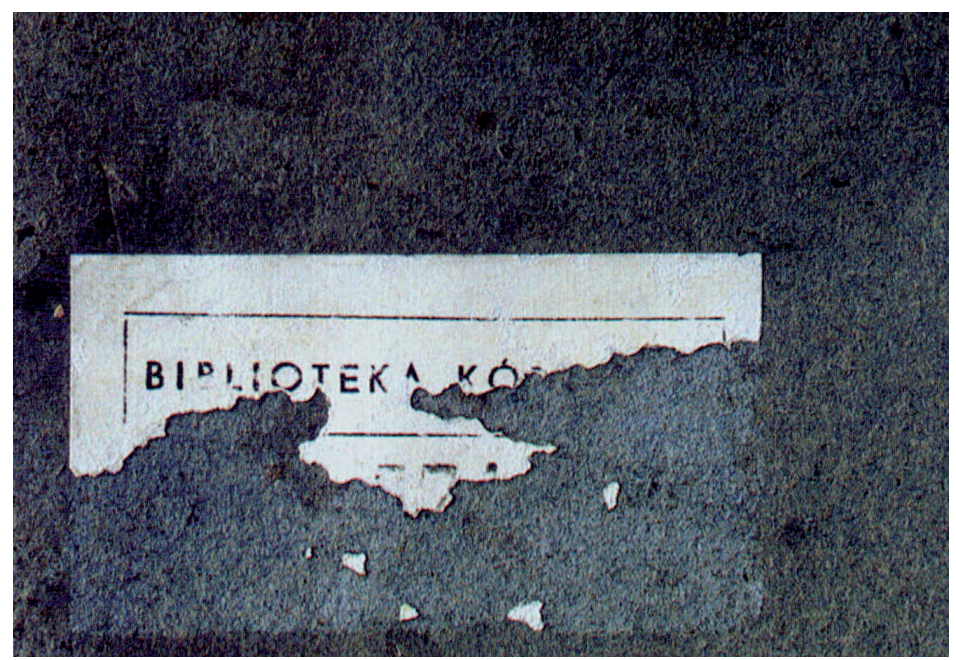

Il. 4. Ubytki naklejki spowodowane żerowaniem rybika cukrowego Lepisma saccharina L. (fot. E. Jabłońska)

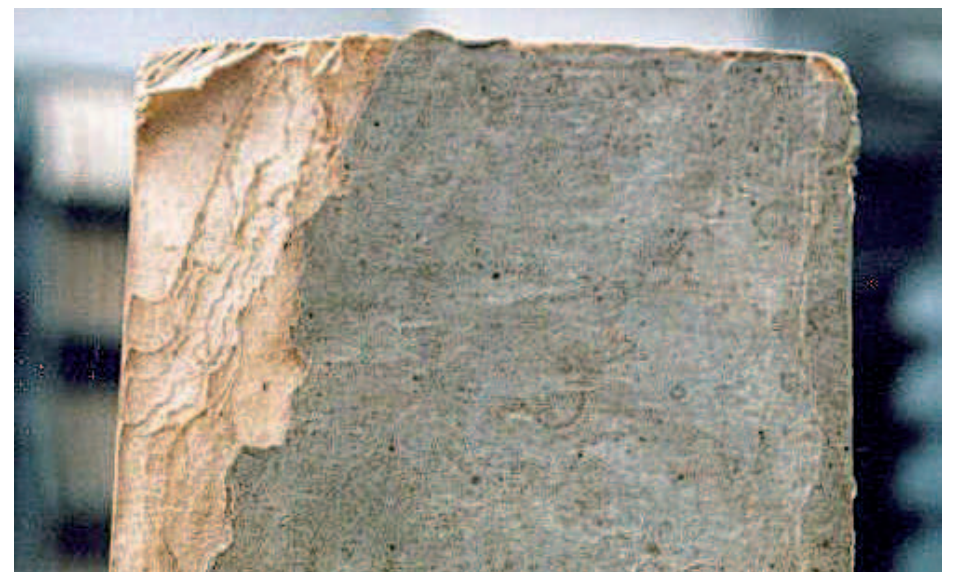

Il. 5. Zniszczenia spowodowane żerowaniem gryzoni (fot. K. Zykubek) 
a)

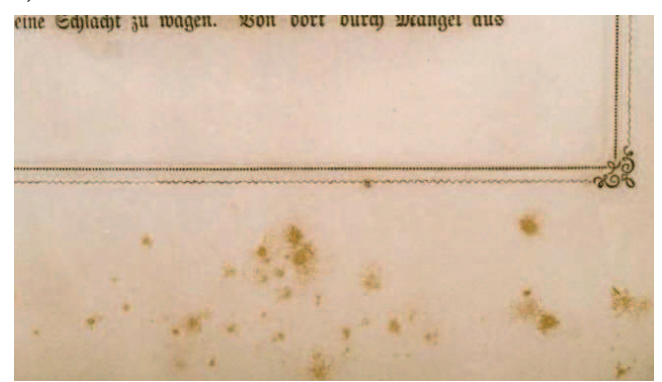

Il. 6. Plamy typu foxing: a) na papierze, b) na płóciennych tasiemkach (fot. K. Zykubek, E. Jabłońska)

a)

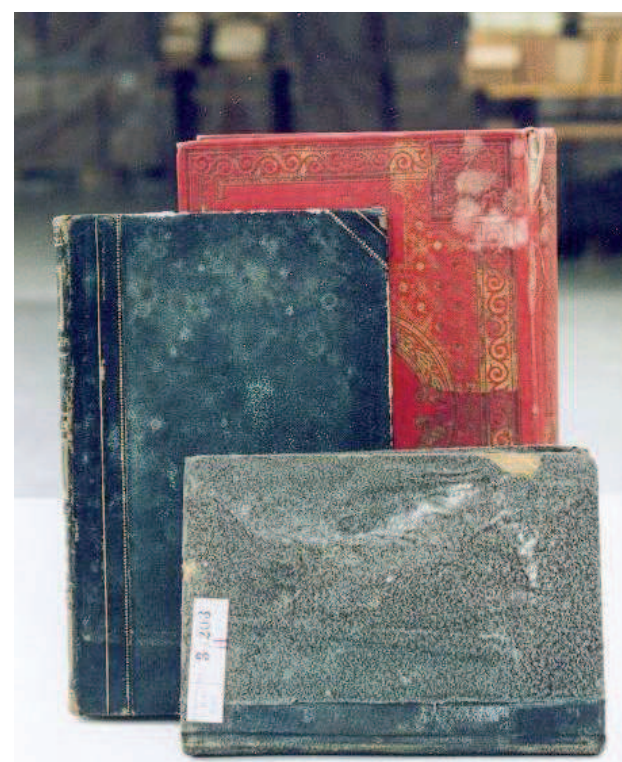

b)

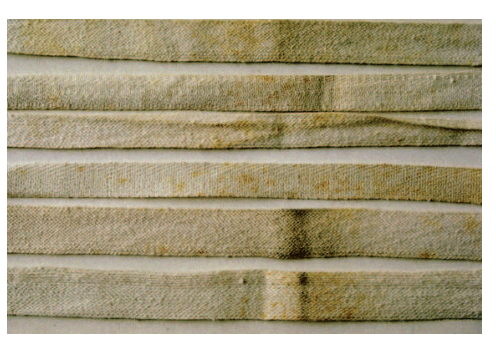

b)

Il. 7. Plamy spowodowane rozwojem grzybów pleśniowych: a) na oprawach, b) na papierze wewnątrz bloku (fot. K. Zykubek)

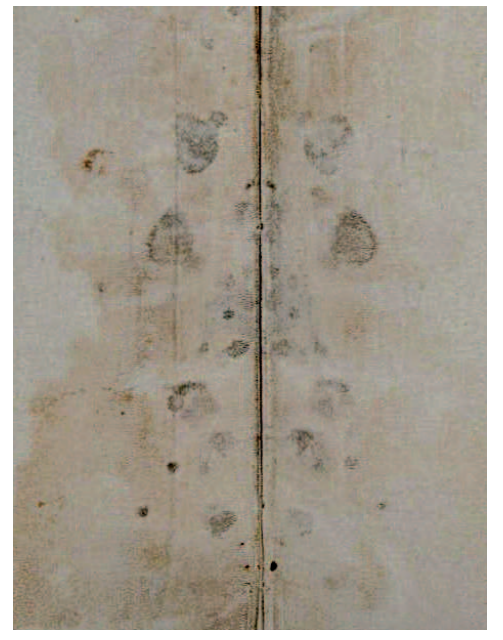

(.) 


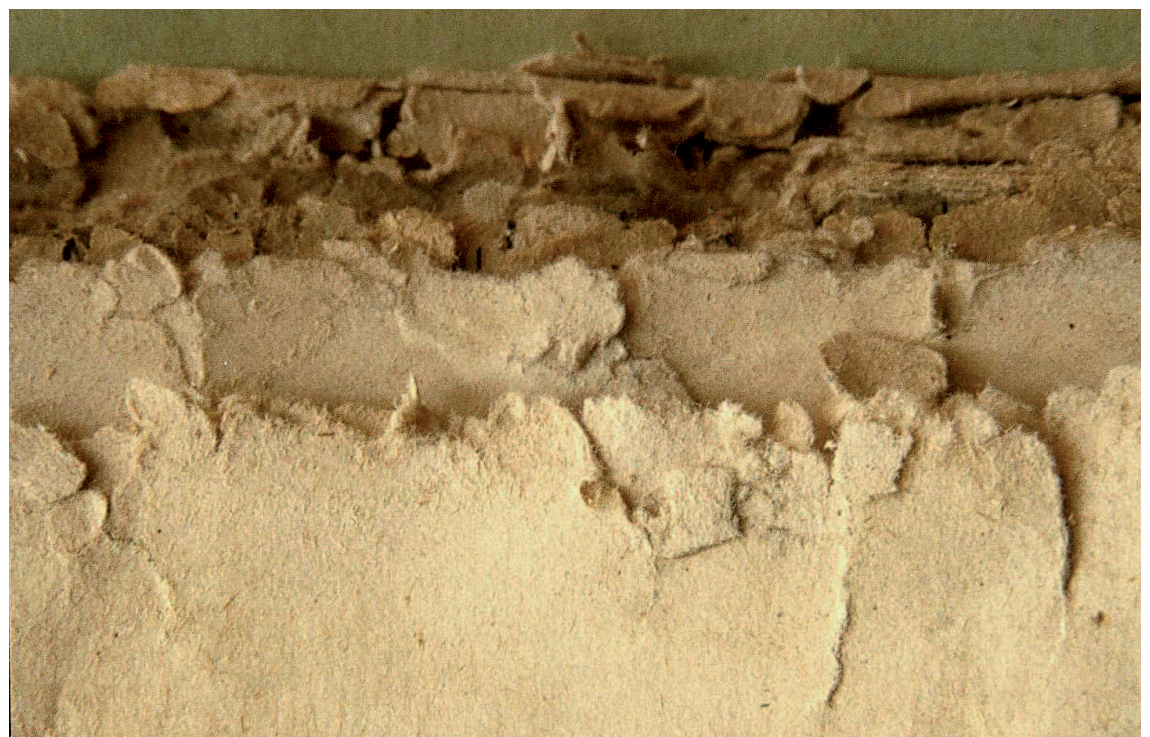

Il. 8. Puszysta destrukcja bloku archiwaliów (fot. K. Zykubek)

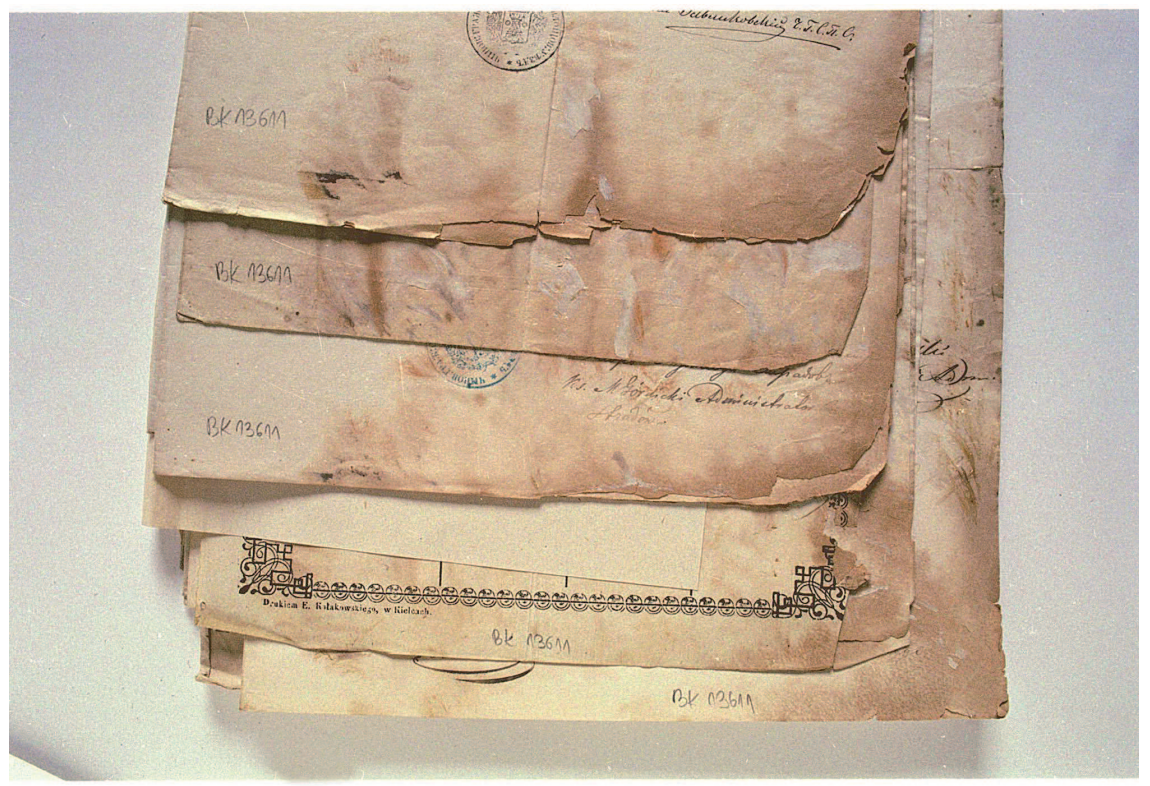

Il. 9. Zbrązowienie papieru i rozwój grzybni podstawczaka (fot. E. Jabłońska) 


\section{Summary}

\section{Biodeterioration of collections in the selected Polish libraries and archives in the connection with storing conditions}

The aims of this work were to assess the biodeterioration of library and archive collections as well as to identify the causes of the destructive processes. The investigation was carried out in five selected storerooms with particular attention being paid to the accumulation of moisture on wall barriers. The measurements of air relative humidity $(\mathrm{RH})$ and temperature as well as the assessment of the biodeterioration of the collections were performed. The samples taken from the objects attacked by microorganisms were microbiologically tested.

A direct dependency between the defects of buildings and the accumulation of moisture on wall barriers was confirmed. The source of moisture accumulation in some storerooms were rainwater penetrating the interior of the rooms through a leaky emergency door, through cracks in roof or terrace coverings or water from the overfilled manholes. The floodings resulted in the water stains on walls and ceilings, flaking of paint coatings, or sometimes colourful deposits of moulds or salts.

The average values of the air $\mathrm{RH}$ in the examined storerooms ranged between $46.0 \%$ and $47.4 \%$. However, it was noted that this parameter highly fluctuated up to $30 \% \mathrm{RH}$ during a year. The average temperatures were between 19.5 and $21.0^{\circ} \mathrm{C}$, which means they were around 1.5 to $3^{\circ} \mathrm{C}$ higher than temperatures recommended for library and archive collections. The temperature values were also variable and, to a large extent, dependent on the outdoor conditions.

Around a quarter of collections in all examined storerooms was, to a larger or lesser degree, damaged by living organisms (fungi, insects and rodents). Some of the threats were still up-to-date, e.g. the attack of insects in one of the storerooms. However, a great number of other damage, in particular caused by microorganisms, has its beginnings in the past and the microorganisms responsible for the damage may have been inactive for a long time now. Hence, it is very difficult to find a correlation between the results of microscope examinations of deposits taken from the attacked places and the results of cultivation of microorganisms from the same spots. The collections had been stored in the examined storerooms for a relatively short period of time between 
10 and 30 years. Their condition of preservation was, to a larger degree, affected by violent conditions (storing in basements, storing in attics, moving places, wars) and moisture, which had accumulated for decades before the collections were placed in the examined storerooms. 